How to Cite

Suasthi, I. G. A., Suda, I. K., \& Suwardani, N. P. (2019). Building religious behavior for grhasta ashrama based on tri hita

karana. International Journal of Humanities, Literature \& Arts, 2(1), 32-39. https://doi.org/10.31295/ijhla.v2n1.93

\title{
Building Religious Behavior for Grhasta Ashrama Based on Tri Hita Karana
}

\author{
I Gusti Ayu Suasthi \\ Indonesian Hindu University, Denpasar, Indonesia \\ Corresponding author email: ayusuasthi@unhi.ac.id \\ I Ketut Suda \\ Indonesian Hindu University, Denpasar, Indonesia \\ Email: suda.unhidps@yahoo.co.id \\ Ni Putu Suwardani \\ Indonesian Hindu University, Denpasar, Indonesia \\ Email: psuwardani@yahoo.com
}

\begin{abstract}
The local wisdom of Tri Hita Karana originating from the teachings of Hinduism is a pattern of development in Sukawati Village. Tri Hita Karana teaches concern for nature, people and Balinese culture. This is intended to perfect vertical relations with the Creator, in order to strengthen faith in God, and horizontally establish good social relations, give each other and help each other. Forming solidarity and togetherness and strengthening brotherhood and unity, the village government along with community leaders, Sukawati Village continues to develop religious behavior ashrama grhasta. This is because there are very rapid changes in the times, therefore as an ashrama grhasta or parents have the role of being the first and foremost educators to build tri hita karana based religious behavior. In the parhyangan aspect an understanding of the teachings of pramana, adhikara, and guarding the sanctity of the temple was built. While in the pawongan aspect raising awareness as members of the banjar carry out social obligations (grief). Then in the palemahan aspect increases awareness to keep the great bhuana along with the elements of the supreme muta bhuta, this is because the elements form the human physical body or often referred to as the altar. With an explanatory approach it was found that the ashrama grhasta still had the spirit of building religious behavior, then in the parhyangan aspect they were fathering, arranging punia funds, ngaturang bhakti as a form of sradha bhakti (faith and piety) in the omnipotence of Brahman (God). In the pawongan aspect the increasing culture of Vasudeva kutumbhakam (we are all brothers), and the principle of tat wam asi (you are me). In the aspect of palemahan they actively participated in the clean Friday movement program. This finding also contributed through the preservation of tradition, religious culture, and preserving the natural environment of the people of Sukawati Village, Gianyar, Bali.
\end{abstract}

Keywords---grhasta ashrama, religious behavior, tri hita karana.

\section{Introduction}

Tri hita karana contains Hindu values that encourage kindness and compassion, and care for the natural environment with generosity to achieve harmony, peace, and happiness. The concept of tri hita karana has become an important topic conveyed by President Joko Widodo related to sustainable development. At the International Monetary Fund (IMF-WBG) meeting held on Thursday 11 October 2018 at the Sofitel Nusa Dua hotel in Bali, it was stated that "The concept of tri hita karana, which describes human harmony with God, with others and their nature is the key to happiness". Listening to Jokowi's speech, it can be understood that the purpose of development is to achieve a happy life together (Jagadhita). The concept of Jagadhita is in line with the vision of Sukawati Village, which is to jointly

ISSN 2632-9441

Received Jan20, 2019 / Accepted Jun 18, 2019 / Published Jul 05, 2019 
develop the "free" (clean, cultured, safe and prosperous) village of Sukawati based on Tri Hita Karana towards Jagadhita.

The era of globalization is very influential on life and has an impact on the shifting of moral values of society, including the people in Sukawati. In terms of social and education, Atmadja (2010), states that Balinese people experience actual social disorganization in deviant behavior, which can be divided into three: semantic difficulties, religious conversion, and a strengthening of the culture of consumerism. So that maintaining the moral values or character of the nation is a top priority as one of the principles of education, namely to form a whole person, in the sense of "building his body and building his soul", however small a morality crisis that occurs in society, indirectly will be able to reduce the value -value of the life of the nation and state. According to Danim (2003), education is actually a process of establishing the moral of a civilized society, a society that appears with the face of normal humanity and humanity. That is, the education intended here is more than just a school (education not only community network) but education as a community network (education us community network). To build a tri hita karana conscious human, then maintaining Balinese culture and civilization must be a common goal, to achieve this goal will be more effective through the approach of education.

Perni (2018) and Pujaastawa (2017), explains that the development of education with local wisdom tri hita karana requires harmony and balance of the human element as citizens, this is intended to develop a learning culture, service culture, and work culture based on tri hita karana ideology in building safety, prosperity, peace and happiness together. These are forms of religious behavior. Perbowosari (2018), in his dissertation, showed that parenting parents can improve religious behavior, parenting needs to be maintained and improved from both the nuclear family and extended family. In addition, Astawa (2019), in his research also explained that religious behavior is said to be good because students can increase their beliefs / Sradha about the state of God, belief in Atman, belief in karma phala, reinkarnasi beliefs and belief in moksha. On the religious behavior of the Hindu community, the religious attitude of the community can be seen as being involved in making worship facilities, maintaining sacred buildings, carrying out yadnya ceremonies, performing rituals, meditating to curb bad deeds that can improve the quality of everyday life.

According to Sudira (2014), the ideology of tri hita karana builds micro awareness, that every human being has three basic capital to live happily, namely: (1) atman or soul; (2) prana or the power of the word - wind - eyelash; and (3) angga sarira or body (wadag). One of the elements of tri hita karana is lost or weakened in humans, so happiness will disappear too. This means that angga sarira or a body without atman or soul is a corpse, atman or soul without angga sarira or a body is a spirit or ghost, atman or soul with angga sarira or a body without prana or the power of the word-mate with humans without potential. In the concept of tri hita karana, it is explained that the universe originally had the same origin (ie God). This universe is seen as coming from one garbha "the great womb" of the Almighty God, as stated in Bhagawad Gìtā Chapter VII. Sloka 6 as follows:

“etad-yonīni bhūtāni sarvāñīty upadhāraya, aham kŗtsnasya jagatah prabhavah pralayas tathā Meaning:

Know that all beings that exist (in this world) come from garbha (content) of Me, and I am the origin and fuser of this universe "(Pudja, 1999).

Besides that in Bhagawad Gita Chapter IX. Sloka 8 also states the following:

"Prakŗtim svām avasş̧̧abhya viş̧jāmi punah-punah, bhūta-grāmam imam kŗtsnam avaśam prakrter vaśāt" Meaning:

I created all living things many times through My Prakrti, without their will, (but) with the power of My wisdom (Pudja, 1999).

From the description of the text of the Bhagawad Gitan above, there are three elements which are declared to be Yajňa. These three elements are Prajāpati as God is called the King of living things on this earth. Prajā as the human element and Kāmadhuk is a manifestation of the universe which is symbolized as an inexhaustible female cow (Wiana, 2007). The combination of the three elements harmoniously as a foundation for creating a sense of life that is comfortable, peaceful, peaceful, prosperous, safe, both outwardly and inwardly.

Along with the development of the times, tri hita karana as a philosophy that became the foundation of Bali's existence began to be disturbed. In terms of the weaknesses, some Balinese land is not owned by Balinese. Transfer of land functions and ownership transfer functions will be dangerous because it is certainly not sanctified through the process of upakara. In terms of pawongan there are indications that Balinese people experience moral degradation, Balinese people should have behaviors based on dharma, artha, kama, and moksa, but the signs of a decline in the 
dignity of the Balinese have begun to appear. In terms of parahyangan there is a desacralization of the holy places which are expanding as seen near Pura, a hotel, villa, or cafe was built. In the aspect of pawongan, the nature of selfishness and individualistic nature is increasingly prominent, and in the aspect of palemahan, environmental management no longer heeds the philosophy of trihita karana, it appears from the absence of green open areas. Given the environmental conditions in which individuals grow and develop have been polluted and contradict religious values and moral values, it can affect individual behavior to be less good. Religious values need to be given attention because religion also unites with good and bad behavior. As described in Kekawin Nittisastra IV.10 namely as follows:

Pangdening Kali muurkaning jana wimoha matukar arebut kawiryan. Tan wring raatnya makol lawan bhratara wandhawa, ripu kinayuh paksrayan. Dewa drewya winasa dharama rinurah kabuyutan inilan paada sepi Wyartha ng sapata su prasaasti linebur tekaping adharma muurka ring jagat.

\section{Result and Analysis}

Ideology tri hita karana is a teaching concept of Hinduism that is used as a principle and opinion to give direction and purpose to live life. This way of life continues to grow, so it becomes the norm in a society. The norm in a community determines the behavior of its members because norms are life guidelines that must be done and which should not be done in the community's environment. The existence of politeness norms or ethics that say what must be done is related to good or bad behavior in terms of ethics. This way of life continues to grow and be shared, spread in human social activities including religious and political systems, customs, languages, clothing, buildings, and works of art. This whole thing is called culture which is passed down from generation to generation, as shown in the following figure.

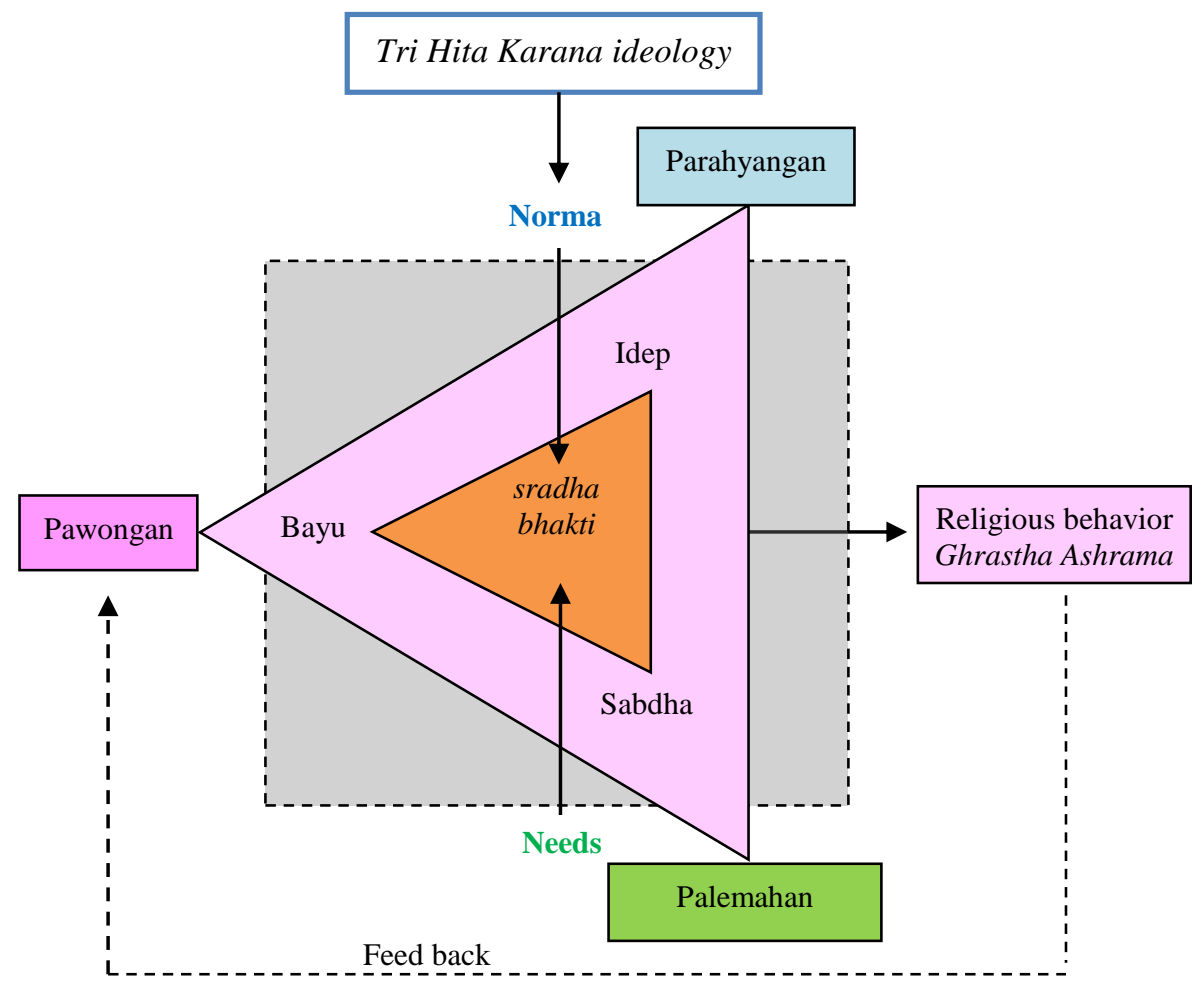

Figure 1. The ideology of tri hitakarana

Individual behavior will reflect the level of needs (needs) according to age and developmental stages, which determine their role in the social life of the community (ghrastha ashrama). In the grahasta (household) stage, individuals are driven to meet the demands of work to make a living to meet family needs. At this stage, parents in 
living life focus more on religious knowledge (widya) and gradually learn to be more willing to let go of sradhabased world bonds. Bhakti (faith and piety) becomes an individual power in living life. First is the cognitive domain (eyelash), this domain for understanding morality teachings, further in the affective domain (bayu) to believe in morality teachings, and finally in the psychomotor realm of grhasta ashrama (parents) ready to carry out religious teachings (sabdha). The implication can be seen how paragraph ashrama has awareness and willingness to perform obligations in social, cultural and religious life as a reflection of religious behavior.

\title{
Building Parhyangan Awareness
}

The purpose of the ashrama grhasta life is to expect a prosperous and happy life. In the book Manavadharmasastra, it is stated that there are several objectives to enter the stages of the dormitory life, namely: (1) Dharmasampatti, this shows a determination, that husband and wife both try to realize dharma in daily life. (2) Praja, this shows that the life of grhasta ashrama also has a noble purpose, which is continuing descent. (3) Rati, in the stages of the ashrama grhasta both enjoy a sexual life that is legitimate by state law and religious law.

This concept leads to a rule that a husband and wife are obliged to worship God and the gods as a form of obligation (dharma) in ashrama grhasta. In the Rigveda Samhita X.85.43, it is stated as follows:

\author{
"Virasup devakama syona \\ Sam no bhava dvipade \\ Sam catuspade"
}

Meaning:

"Households should worship the gods, be friendly, please ancestral spirits to preserve the environment".

(Titib, 1996)

Modern lifestyles have resulted in social unconformity increasingly spread within the community in Sukawati Village. So to restore community togetherness and solidarity, namely by building awareness of parhyangan through understanding the teachings of the pramana word, namely full awareness to increase sradha bhakti (faith and piety), ie diligently reading the scriptures or religious literature, understanding adhikara teachings, namely making worship with bhakti sincere and pure understanding to maintain and care for a holy place or temple.

Education according to Hinduism is expected to have a character of morality and culture based on tri hita karana ideological values. According to Sudira (2014), that building character-based human resources includes learning culture (jnana), work culture (karma), culture of service (bhakti), and mental learning person, namely education which aims to produce character with tri hita culture karana which has nine intelligences (wiweka sanga) based on harmony and balanced values, between humans and their God (parahyangan) as spiritual beings, among fellow humans (pawongan) as social beings, and between humans and the environment (palemahan) as natural beings. Then, Wiweka sanga or multiple intelligence includes spiritual emotional intelligence, ecological social intelligence, intellectual intelligence, kinesthetic intelligence, economic intelligence, political intelligence, technological intelligence, art and cultural intelligence, and intelligence of learning or lifelong learning.

Parhyangan's teachings encourage humanity to carry out sradha and devotional service in organizing life in the world in order to obtain a quality life. Bhagavata Purana VII.5.23 explains that there are nine devotions that should be performed, namely: Sravanam, Kirtanam Visnoh, Sumaranam, Padaseranam, Arcanam, Vandanam, Dasyanam, Sakhyanam, Atmaniwedanam.

Which mean:

1) Sravanam is worshiping God by hearing sacred stories and holy vedic spells.

2) Kirtanam is worshiping God by singing hymns.

3) Sumaranam is worshiping God by remembering God for all its manifestations

4) Arcanam is worshiping God through media statues or pratimas

5) Vandanam is worshiping God by reading sacred stories

6) Dasyanam is worshiping God by devoting himself sincerely with full devotion (ngayah)

7) Padesewanam is worshiping God by prostration surrender, surrender fully to God

8) Sakhyanam is worshiping Who is able to release rajas and tamas traits

9) Atmaniwedanam is worshiping God by surrendering himself totally by working hard (tyaga) without any hope of results and escape from worldly bonds (sannyasa). 
Based on the description of the nine bhakti above, it gives an illustration of the form of devotional service to God (parhyangan) that can be done by grhasta ashrama which includes: (1) Prayer activities or Tri Sandya every day. (2) Preparing the facilities and giving banten in the sulking / refutation in the dwelling place of residence or in the temples of Tri Khayangan, Sad Khayangan and in Pura Dang Khayangan (3) Following the Dharma Discourse either directly or through the media. (4) Singing or listening to the hymns. (5) Running Chess Brata, fasting, fasting Siwaratri day or other days. (6) Following meditation yoga. (7) Participate in designing the construction or caring for a sacred place (refute / rampant). (8) Always keep chastity / purity and sanctuary / temple. (9) Helping (punia funds) for the continuity of the ritual in Pura. (10) Following the training helps and means for each means of offering. (11) Following the activities of Tirta Yatra (spiritual ascent), according to their respective abilities.

\section{Building Pawongan Awareness}

Pawongan is a sosioreligious awareness of the Hindu community in Bali. Thus the basis of this concept is a harmonious relationship between humans and their neighbors and living side by side in a balanced manner and living harmoniously in society with the breath of the teachings of Hinduism. Thus pawongan focuses on harmony in the whole of the bhakti. Religious behavior is cultivated by providing spiritual responsibility to each family head in Sukawati Village to be able to afford to carry out social obligations based on the Hindu religion. Building the religious behavior of grhasta ashrama as a banjar citizen is one of the efforts to develop the teachings of Vasudeva kutumbhakam (we are all brothers) and the teachings of tat wam asi (you are me, I am you). The shape is like: (1) Care for each other in the banjar community. (2) Always participate in social responsibility both joy and sorrow. (3) Carrying out the ngayah task as an application of the concept of pawongan based on Hindu teachings. (4) When one of the banjar residents dies, other residents take part in helping carry out the ceremony and relieve the burden on the residents of the banjar who have been hit by the disaster.

In living a grhastha ashrama life the family should not feel quickly satisfied with the learning outcomes obtained at the formal education level, because in the community there is still much that needs to be learned from each activity or event. The world of life becomes the place for the learning process to take place through interaction with the environment, both with the natural environment, social environment, and local culture. Substitution of natural conditions and socio-cultural changes become learning resources in accordance with the village of Kala Patra. This is in line with what is called etnic learning, namely learning can be done anywhere, anytime, starting from the family environment, workplace, and in the community. As described by Suardana (2018), tri prana can be said to be a conception or three ways / ways to know the nature of truth from a real or abstract matter.

Tri pramana includes pramana, pramana anumana, and pratiyaksa pramana. Likewise Sukarma (2018), asserts that true knowledge is called prama and the means of gaining knowledge is called pramana consisting of pratyaksa (observation), anumana (conclusion), upamana (comparison), and sabdha (testimony). Stewardship is the power that gives birth to the predicate of being able to (know and able), ririh (know and sangup), and wikan (years and wise) As explained in the book Atharvaveda Samhita III.30.5, as follows.

Jyayasvantas cittino ma'vi yausta

Sam radhayantah sadhuras-carantah Anyo anyasmi algu vadanta

Eta'sadhricinam vah samanasaskr'nomi

Meaning :

"O humanity, advance with society and mutual understanding. Being in the same mind. Fight together, and I unite you with noble thoughts." (Sayanacarya. 2005)

The concept of Pawongan teachings encourages people to maintain tolerance among others, build unity by realizing harmonious togetherness. Mantra Rg. Vedic X.191.4 (Wiana, 2007), provides a strong foundation for maintaining the unity of life as follows:

Samani va akutih samana hrdayani vah,

Samanamastu vo mano yatha vah susahasati

Meaning:

O mankind, may you advance with the same intentions. May your heart (your heart) and your mind be with each other. So you can be organized (arranged) uniformly. 
Reading to the contents of the spell above can actually be used as a guide to implementing the concept of parade in the activities of daily life. Likewise happiness will be felt if human beings can respect each profession / business occupied by the people in accordance with their potential. The following are some forms of grhasta ashrama activities related to the aspects of pawongan as follows: (1) Planning, guiding education and health of children and families. (2) Applying discipline and division of tasks to children. (3) Also directs children to choose career / career guidance. (4) Also active in ngopin activities (mutual cooperation to help neighbors). (5) Helping education by donating funds / educational facilities. (6) Join social organizations.

\section{Building Palemahan Consciousness}

Building Palemahan's awareness through the understanding of the great bhuana as an element or element of the universe called the maha bhhuta which forms the physical body of a human as a bhuana, so that humans must strive to be in harmony with nature. There are five physical elements of the universe, namely: (1) What is water. Like the human body contains water, blood vessels, digestion, lungs and so on. (2) Teja, namely rays, or heat. For example, the body's temperature or human digestion comes from the heat of fire (digestive fire). (3) Bayu namely Wind, the human body is made of wind / air. (4) Prety is Land. Skin, and made entirely of elements in the soil. (5) Akasa is space or cavity.

In line with this, the 5th mantra of the Tri Sandya Bait contains the meaning and emphasis that the great bhuana (universe) must be balanced and harmonious with the natural bhuana (human self). Grhasta ashrama in Sukawati village believes that the Tri Sandya prayer has an impact on the welfare and balance of nature, the mantra is as follows.

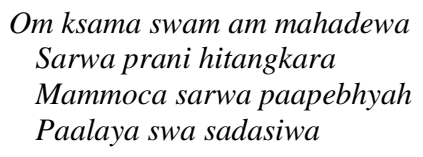

"O Lord, what is called Mahadewa. Give prosperity to the entire universe and the safety of all living things"

Likewise Rg. Vedic recommends that humans do real to protect the earth with all the wealth in it which contains elements of minerals and metals as a source of human life. Mantra Rg. Vedic III.51.5 explains:

\section{Indraya dyava osadhir utapo rayim raksanti jirayo vanani.}

Meaning:

Protect natural resources such as atmospheric, plants, and medicinal plants, rivers, water sources, and wilderness.

\section{In Ayurveda XVIII.13 Explain:}

Hiranyam ca me yasca me

Syamam ca me lokam ca me

Sisam ca me trapu ca me

Meaning:

Hopefully we get the metals contained in the earth, namely gold, iron, copper, steel, red metal, lead, zinc and tin.

Hinduism and Balinese culture are very rich in local wisdom both in concept form and in expressions, symbols, with their appearance that is beautiful, attractive, and full of the meaning of spirituality. Tri hita karana is one of the local wisdoms of the teachings of Hinduism. Therefore, it can be said that Balinese (Hindus) have an awareness and belief that these three elements contain very basic, profound, and universal meanings. As long as humans use nature by referring to religious teachings which are mandated in the concept of tri hita karana, it is certain that nature will never be exhausted especially until it causes disaster. The use of forests and crops which are balanced with replanting implies mutual symbiosis between humans and the natural environment including animals. This pattern can be said to have implemented the teachings / elements of palemahan. 
In Sukawati village, degradation occurred in the palemahan aspect. There has been a change in the use of telajak / ambal - the ambush which was supposed to be used as a green open space with a variety of flower plants, and fruits, instead it was intended as a social activity or menyamabraya. From one side there appears to be a shift, namely the taxation which was originally intended for green open space is actually used for building kiosks / stalls as economic activities. As implied in the awig - awig Pakraman Sukawati Village in 1991, palet 6, pawos 23, which regulates the traditional spatial layout of Pakraman Sukawati Village, explaining that:

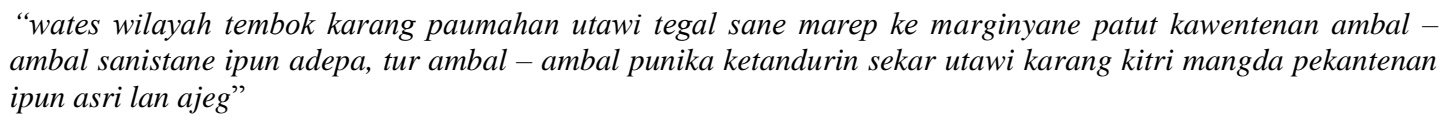

Meaning:

The boundaries of the housing walls and gardens facing the highway must be provided by the ambulance or the telajak (green open space) which can be planted with various flowers and other plants to make them look beautiful and sustainable.

In the current situation nature with all its contents or the earth has been very burdened as a result of Global Warning, thus making the earth or motherland as the god of the earth increasingly miserable. From some of the holy mantras above, it gives instructions to implement in real life which include: (1) Planning the construction of a residence or place of business with regard to the still architecture of Bali, adhering to awig - awig about hanging shoes (not going beyond other buildings or areas). (2) Plan to use raw materials or raw materials and recycle their business waste, such as actively sorting out organic and inorganic waste. (3) Purchasing equipment or machinery that is environmentally friendly. (4) Planting, maintaining plants or plants or pets in the household environment. (5) Participating in Bali Green and Clean through related organizations (PKK, Darmawanita, IWAPI etc.). (6) Carrying out the Bhuta Yad ceremony is like the latest in the household environment and the environment of Pekraman village. (7) Utilizing tools and facilities for intact religious services used again. (8) Using technology tools at home and at the place of business as efficiently as possible. (9) Using clean water and electricity efficiently. (10) Arrange for help on the day of the sling, the cage, tumpek uduh, tumpek puppets and tumpek Krulut.

This process emphasizes grhasta ashrama as a pioneer to become agents of change and environmental conservation. Thus the effort to preserve the environment is the main thing in the process of developing palemahan awareness among the ashrama grhasta.

\section{Conclusion}

Modern lifestyles result in wider social inequality in the community in Sukawati Village. To restore community togetherness and solidarity, namely by building (1) parhyangan awareness through understanding the teachings of the pramana ie full awareness to increase faith and piety diligently reading the scriptures or religious literature, understanding adhikara teachings namely carrying out devotions with sincere and pure devotion, understanding to maintain and care for a holy place or temple. (2) Building awareness of pawongan namely increasing awareness as members of the banjar and tempekan, helping to maintain security and comfort by carrying out social obligations (grief), carrying out joint decisions to launch religious ceremonies, and as siva-sis namely building awareness to ask for guidance from clergy or sulinggih in the local environment associated with religious ceremonies to conform to religious literature. (3) Building the awareness of palemahan through the understanding of the great bhuana as an element or element of the universe called the maha bhhuta which forms the physical body of a human as a bhuana, so that humans must strive to be in harmony with nature. Understanding of renewal rituals to keep humans in harmony and harmony with nature, because the means of innovation are believed to be able to neutralize (nyomia) negative forces into positive forces. Understanding the mutual cooperation system as a form of human effort to protect, care for, preserve and protect nature.

\section{References}

Astawa, I. N. T. (2019). Keluarga sebagai pengembang pendidikan karakter anak. Adi Widya: Jurnal Pendidikan Dasar, 1(1), 73-81.

Atmadja, N. B. (2010). Ajeg Bali: gerakan, identitas kultural, dan globalisasi. Penerbit \& distribusi, LKiS.

Danim, S. (2003). Agenda pembaruan sistem pendidikan. Pustaka Pelajar. 
Perbowosari, H. (2018, January). Peran Kecerdasan Emosional Dalam Pendidikan Karakter. In Prosiding Seminar Nasional Pendidikan Guru Sekolah Dasar Hindu (pp. 167-174).

Perni, N. N. (2018). Upaya meningkatkan keterampilan membaca wacana beraksara bali melalui penerapan model pembelajaran kooperatif think-pair-share. Jurnal Imiah Pendidikan dan Pembelajaran, 2(3), 359-367.

Pudja, G. (1999). Theologi Hindu (Brahma Vidyā): satu pengantar tentang pokok-pokok ajaran ketuhanan menurut ajaran Hindu sebagaimana diuraikan dalam Veda. Paramita.

Pujaastawa, I.B. G.(2017). Desa Wisata Penglipuran Model Pengelolaan Daya Tarik Wisata Berbasis Tri Hita Karana. Jnana Budaya: Media Informasi Sejarah, Sosial, dan Budaya, 22(1).

Sayanacarya, B. O. (2005). Atharvaveda Samhita I.

Suardana, R. (2018). Manajemen Tri Pramana. Wartam/Edisi, 35.

Sudira, P. (2014). Konsep dan Praksis Pendidikan Hindu Berbasis Tri Hita Karana. Jurnal Ilmiah, 23(01.8).

Sukarma, I. W. (2018). Memaknai Bahasa dan Membahasakan Makna dalam Penulisan Buku Hindu. VIDYA WERTTA: Media Komunikasi Universitas Hindu Indonesia, 1(2), 1-6.

Titib, I. M. (1996). Veda Sabda Suci Pedoman Praktis Kehidupan. Surabaya: Paramita.

Wiana, I. K. (2007). Tri Hita Karana Menurut Konsep Hindu. Surabaya: Paramita. 